- flexibility that ESA has to achieve this would be to delay future missions, while trying to avoid a detrimental knock-on effect.

What are the realistic options for an affordable, scaled-down version of Cluster? One possibility would be to fly a single satellite with simpler scientific instruments. One back-up satellite already exists and could be prepared quickly and reasonably cheaply by the German contractor, Dornier.

A second possibility would be to launch the back-up satellite along with one or more smaller, simpler and cheaper satellites. But this would require much more time, as the design of any new satellite would need to be extensively tested.

In either case, ESA will be looking at the possibility of putting any replacement satellite or satellites into orbit with other ISTP spacecraft, in an attempt to reproduce the three-dimensional resolving power characteristic of Cluster's four-satellite set-up, which scientists are keen to protect.

In both cases, the reduced weight of the mission would allow a cheaper launcher such as Ariane-4 - to be used. In both cases, however, even if ESA was able to find sufficient money to provide the replacement satellites, national space agencies would have to agree to pay once again for the instruments, despite extreme tightness of their own funds.

Alison Abbott

\title{
NIH resists bill to promote research into Parkinson's
}

Washington. Support is growing in the US Congress for a bill that would dramatically increase spending on research into Parkinson's disease by the National Institutes of Health (NIH) - despite the opposition of leading NIH officials who dislike congressional mandates.

The bill, named after Morris K. Udall, a popular former congressman, has 42 Senate co-sponsors and 176 supporters in the House of Representatives, ranging from conservative Republicans to liberal Democrats - a "dream" list, according to one Senate aide. Between 1 and 1.5 million Americans are believed to suffer from Parkinson's disease. One estimate puts the cost of their care at $\$ 25$ billion a year. The bill authorizes more than $\$ 100$ million a year for Parkinson's research over five years, compared to $\$ 28$ million at present.

Advocates describe the present sum, much of which is channelled through the National Institute of Neurological Disorders and Stroke (NINDS), as paltry compared to that allocated to diseases such as Alzhei-

\section{Chinese rocket site 'blind to safety'}

Hong Kong. An internal memorandum from the international satellite company Intelsat, criticizing a "blindness towards safety" at China's rocket launch site and describing it as "pathetically short of world standards", has added to the aerospace industry's growing concerns about the viability of China's commercial satellite launch capabilities.

The memorandum, which was obtained by the Washington-based publication Science and Government Report, reports what it claims to have been "callous disregard for human life" and states that "under no circumstances" can Intelsat use the site again. It is written by a manager who witnessed the explosion on 14 February during attempted lift-off on the first flight of a Long March 3B rocket of Intelsat's 708 satellite from the space site at Xichang in Sichuan province.

Although China's Great Wall Industry Corporation, which runs the launch facility, reported four deaths, Israeli film footage smuggled out afterwards showed soldiers clearing bodies and wreckage over a large area. The film-maker estimated that a hundred people had been killed. In another disaster in January 1995 , six people were officially reported killed at the inland military site, which is in a mountainous region popu- lated by farmers.

The Intelsat memo says observers were prevented from leaving the viewing area for nine hours after the explosion. "In retrospect, this gave the Chinese enough time to clear out any dead people from the gate and village areas, which were not evacuated to our knowledge," the memo says.

Great Wall declines to comment on either its launch schedule or the site's safety. Since the disaster, however, two planned Intelsat launches, one by the US-based company Echostar and a fourth by Asia Satellite Communications (AsiaSat), based in Hong Kong, have been moved to Russia's Proton and France's Ariane rockets.

February's failure contrasts sharply with that of Ariane (see page 241), in which the rocket was blown up from the ground within a few seconds of launch. The Long March 3B was allowed to fly for 20 seconds and to turn until it was heading back to Earth, even though television footage clearly showed it turning off-course before it had even cleared the launch tower. Some observers speculate that either the Chinese held off to avoid damaging the launch tower or that their rocket was not carrying explosives capable of destroying the vehicle in case of difficulties.

Elisabeth Tacey mer's and AIDS. They have now convinced many politicians of their case. Even conservative opponents of fetal tissue transplants - which NIH Parkinson's money now supports - have signed on as co-sponsors, even though the bill does not contain a ban on NIH funding of such research.

One such senator, Rick Santorum (Republican, Pennsylvania), has "some reservations" about the bill because of this, says his spokesman, Tony Fratto. "But we felt that [Parkinson's disease] is so important that we need to give the bill as much support as possible." Other senators, such as Dan Coats (Republican, Indiana), who vocally oppose congressional "earmarking" of NIH funds, are making an exception and supporting the Parkinson's bill.

Zach Hall, the director of NINDS, declines to comment on the bill, but says his institute is "very actively concerned" with Parkinson's.

Harold Varmus, the director of NIH, questioned in March by the Senate Committee on Labor and Human Resources, said he opposed the bill. He argued that the longedfor advances in Parkinson's research would come about not by quadrupling funds directed at Parkinson's but from "work that is generic to all nerve cells".

But Paul Wellstone (Democrat, Minnesota), both of whose parents had the disease, challenged Varmus, saying that many people struggling with the illness "are not at all persuaded" that generic research is enough. Citing "no increase at all" in funding for Parkinson's by NIH since 1989, Wellstone said: "I don't see that much of a commitment.”

Varmus replied that he feared the NIH could not "responsibly fund" ten Parkinson's research centres, as required by the bill. "We don't believe that science would be furthered by such a large expenditure of money for so many centers," he said. He also called on the committee - which is responsible for drafting a separate bill that authorizes the $\mathrm{NIH} \mathrm{-} \mathrm{to} \mathrm{preserve} \mathrm{"an} \mathrm{atmosphere} \mathrm{as} \mathrm{free}$ as possible from restrictions" requiring the $\mathrm{NIH}$ to spend money on certain diseases. The Udall bill was introduced in 1995. Its House author is Henry Waxman (Democrat, California), and its Senate author is Mark Hatfield (Republican, Oregon).

The bill's advocates hope that the Senate Committee on Labor and Human Resources will soon amend a bill reauthorizing the NIH to include the Udall bill. But chairwoman Nancy Kassebaum (Republican, Kansas), opposes additions to the NIH bill, and its House counterpart is unlikely to see legislative action this year, according to aides.

Meredith Wadman 